\title{
Impact of Brassica and Lucerne Finishing Feeds and Intramuscular Fat on Lamb Eating Quality and Flavor. A Cross-Cultural Study using Chinese and non-Chinese Australian Consumers.
}

Damian Frank ${ }^{1}$, Peter Watkins ${ }^{2}$, Alex Ball ${ }^{3}$, Raju Krishnamurthy ${ }^{1}$, Udayasika Piyasiri ${ }^{1}$, James Sewell ${ }^{4}$, Jordi Ortuño ${ }^{1}$, Janet Stark ${ }^{5}$ and Robyn Warner ${ }^{6}$

${ }^{1}$ Commonwealth Scientific Industrial Research Organisation (CSIRO), 11 Julius Ave, North Ryde, NSW, 2113, Australia. ${ }^{2}$ Commonwealth Scientific Industrial Research Organisation (CSIRO), 671 Sneydes Rd., Werribee, Vic. 3030, Australia. ${ }^{3}$ Meat \& Livestock Australia (MLA), Level 1, 40 Mount Street, North Sydney, NSW, 2060, Australia.

${ }^{4}$ PGG Wrightson Seeds (Australia) Leigh Creek Research Station, 4 Blackswamp Rd, Leigh Creek, Vic 3052, Australia, ${ }^{5}$ Commonwealth Scientific Industrial Research Organisation (CSIRO), 39 Kessels Rd, Coopers Plains, QId. 4108, Australia

${ }^{6}$ Faculty of Veterinary and Agricultural Science, The University of Melbourne, Royal Parade, Parkville, Vic 3010

*Corresponding author: Damian Frank, CSIRO, 11 Julius Ave, North Ryde, NSW 2113.

Tel: +61294908584

Fax: +61294908499

E-mail: damian.frank@csiro.au 
Table S1: List of the odor, flavor, taste, aftertaste and texture attributes used to measure grilled lamb sensory attributes

\begin{tabular}{|c|c|c|c|c|c|c|c|c|c|}
\hline ODOR & Descriptor & Anchor & & $\begin{array}{l}\text { Reference } \\
\text { Standard }\end{array}$ & TASTE & Descriptor & Anchor & & $\begin{array}{l}\text { Reference } \\
\text { Standard }\end{array}$ \\
\hline Lamb / mutton & odor of cooked lamb & low to high & & & Sweet & $\begin{array}{l}\text { intensity of sweet } \\
\text { taste }\end{array}$ & low to high & & sugar solution \\
\hline Grilled & $\begin{array}{l}\text { Odor generated by } \\
\text { grilling }\end{array}$ & low to high & $\begin{array}{l}\text { barbeque, } \\
\text { roasted }\end{array}$ & & Salty & intensity of salty taste & low to high & & salt solution \\
\hline Bloody & Odor of fresh blood & low to high & raw meat & lamb blood juice & Sour /acidic & $\begin{array}{l}\text { intensity of } \\
\text { sour/acidic taste }\end{array}$ & low to high & & $\begin{array}{l}\text { citric acid } \\
\text { solution }\end{array}$ \\
\hline Caramel & Odor of burnt sugar & low to high & & $\begin{array}{l}\text { caramelized sugar } \\
\text { solution }\end{array}$ & Umami & $\begin{array}{l}\text { intensity of umami } \\
\text { taste }\end{array}$ & low to high & & $\begin{array}{l}\text { monosodium } \\
\text { glutamate (MSG) }\end{array}$ \\
\hline Barnyard & $\begin{array}{l}\text { Odor of barnyard or } \\
\text { stables }\end{array}$ & low to high & $\begin{array}{l}\text { cow pat, Easter } \\
\text { show, urine }\end{array}$ & p-cresol (1 ppm) & $\begin{array}{l}\text { AFTERTASTE / } \\
\text { AFTERFEEL }\end{array}$ & & & & \\
\hline Hay /grainy & $\begin{array}{l}\text { Odor of dry hay or } \\
\text { grains }\end{array}$ & low to high & $\begin{array}{l}\text { hay bale, dried } \\
\text { grass }\end{array}$ & & Acidic & $\begin{array}{l}\text { residual acidic / sour } \\
\text { taste }\end{array}$ & low to high & & \\
\hline Livery & Odor of grilled liver & low to high & & grilled beef liver & Astringency & $\begin{array}{l}\text { Dry sensation on } \\
\text { mouth surfaces }\end{array}$ & low to high & & \\
\hline Oxidized fat & Odor of rancid fat & low to high & rancid, stale, & & $\begin{array}{l}\text { Oily } \\
\text { mouthcoating }\end{array}$ & $\begin{array}{l}\text { Amount of oil left on } \\
\text { mouth surfaces }\end{array}$ & $\begin{array}{l}\text { None to } \\
\text { much }\end{array}$ & $\begin{array}{l}\text { greasy, } \\
\text { fatty }\end{array}$ & \\
\hline FLAVOR & & & & & Metallic & $\begin{array}{l}\text { The residual intensity } \\
\text { of iron taste }\end{array}$ & low to high & & \\
\hline Overall impact & Overall flavor intensity & low to high & & & Lingering & $\begin{array}{l}\text { Aftertaste } 30 \text { seconds } \\
\text { after swallowing }\end{array}$ & low to high & & \\
\hline Lamb /mutton & Flavor of cooked lamb & low to high & & & TEXTURE & & & & \\
\hline Dairy & $\begin{array}{l}\text { Flavor of milk and } \\
\text { butter }\end{array}$ & low to high & $\begin{array}{l}\text { milk, butter, } \\
\text { cream }\end{array}$ & unsalted butter & Tenderness & $\begin{array}{l}\text { Tenderness while } \\
\text { chewing }\end{array}$ & $\begin{array}{l}\text { tough to } \\
\text { tender }\end{array}$ & & \\
\hline Grassy & $\begin{array}{l}\text { Flavor of freshly cut } \\
\text { grass }\end{array}$ & low to high & green, leafy & $\begin{array}{l}\text { hexanal solution ( } 20 \\
\text { ppm) }\end{array}$ & Juiciness & $\begin{array}{l}\text { Amount of juice } \\
\text { released }\end{array}$ & none to a lot & & \\
\hline Vegetal & $\begin{array}{l}\text { Flavor of cooked } \\
\text { cabbage/brassicas }\end{array}$ & low to high & Broccoli, & $\begin{array}{l}\text { Greenland Brassica } \\
\text { microwaved } 1 \mathrm{~min} \\
\text { and cooled }\end{array}$ & $\begin{array}{l}\text { Number of } \\
\text { chews }\end{array}$ & $\begin{array}{l}\text { Number of chews to } \\
\text { swallow }\end{array}$ & $\begin{array}{l}\text { Count } \\
\text { number }\end{array}$ & & \\
\hline Fatty & $\begin{array}{l}\text { Flavor associated with } \\
\text { oil }\end{array}$ & low to high & & & $\begin{array}{l}\text { Connective } \\
\text { tissue }\end{array}$ & $\begin{array}{l}\text { Amount of connective } \\
\text { tissue/fibrous }\end{array}$ & $\begin{array}{l}\text { none to } \\
\text { much }\end{array}$ & sinew & \\
\hline
\end{tabular}

$\begin{array}{ll}\text { Livery } & \text { Flavor associated with low to high } \\ \text { grilled liver }\end{array}$

Metallic Flavor associated with low to high minerals, iron iron tablet

iron low to high tablets solution




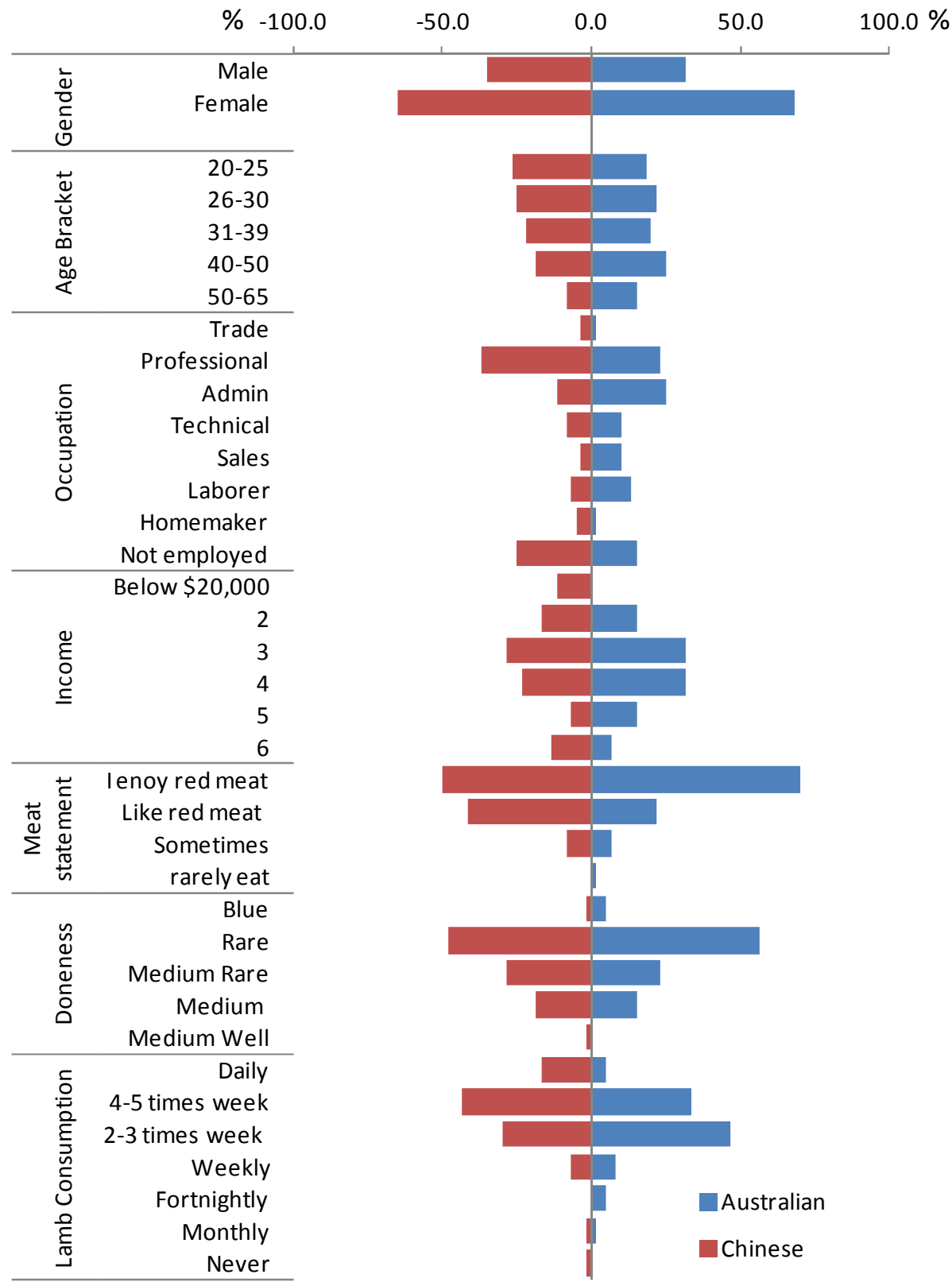

Figure S1: Summary of demographic breakdown for the Chinese and Non-Chinese background consumers 